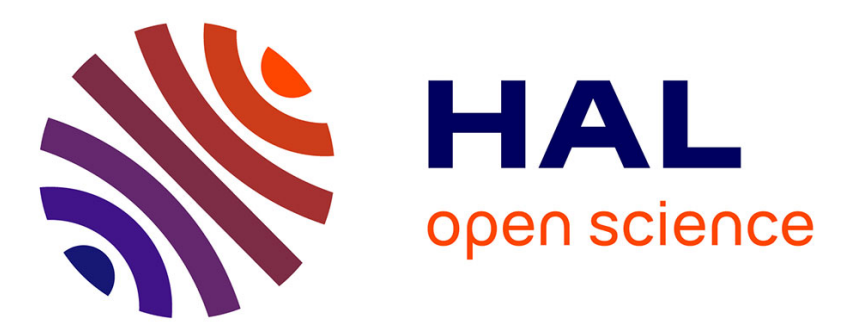

\title{
Influence of orbital forcing on the seasonality and regionality of the Asian Summer monsoon precipitation
}

\author{
M. E. Hori, M. Abe, T. Yasunari, A. Kitoh
}

\section{To cite this version:}

M. E. Hori, M. Abe, T. Yasunari, A. Kitoh. Influence of orbital forcing on the seasonality and regionality of the Asian Summer monsoon precipitation. Climate of the Past Discussions, 2008, 4 (3), pp.719-740. hal-00298226

\section{HAL Id: hal-00298226 \\ https://hal.science/hal-00298226}

Submitted on 9 Jun 2008

HAL is a multi-disciplinary open access archive for the deposit and dissemination of scientific research documents, whether they are published or not. The documents may come from teaching and research institutions in France or abroad, or from public or private research centers.
L'archive ouverte pluridisciplinaire HAL, est destinée au dépôt et à la diffusion de documents scientifiques de niveau recherche, publiés ou non, émanant des établissements d'enseignement et de recherche français ou étrangers, des laboratoires publics ou privés. 


\section{Influence of orbital forcing on the seasonality and regionality of the Asian Summer monsoon precipitation}

\section{Influence of orbital parameter on the Asian monsoon \\ M. E. Hori et al.}



Printer-friendly Version

Interactive Discussion 


\section{Abstract}

The response of Asian monsoon precipitation to contrasting orbital parameters is simulated using the MRI-CGCM climate model. Results show that for the $125 \mathrm{kya}$ B. P. experiment, a large continental heating due to obliquity forcing is apparent and accounts 5 for the strengthened cross equatorial flow, stronger monsoon westerly over the Arabian Sea, and an enhanced precipitation over the Indian subcontinent. For the 115 kya B. P. experiment, while the monsoon westerly becomes weaker in the Arabian Sea, the overall strength of the monsoon westerly becomes stronger in the Bay of Bengal. This eastward extension of the monsoon westerly converges with the equatorial dochina peninsula. Such increase in precipitation is accompanied with an earlier onset of the Asian monsoon, and an earlier warming of the tropical SST due to precessional forcing. It is concluded that while the obliquity forcing creates the baseline land-sea contrast which maintains the Asian monsoon westerly, when such forcing is comparably weaker, the Indian monsoon is diminished and the precessional forcing becomes more dominating to create a distinct earlier warming of the tropical SST which leads to an earlier onset of the maritime monsoon over the western Pacific. This study implies that even under weaker insolation forcing, the precessional signal may act to enhance certain regional precipitation and onset timing of the Asian monsoon.

\section{Introduction}

Understanding the monsoon variability of the past from paleoclimate records gives valuable information for projecting the future change in this highly populated region.

In the orbital timescales, past studies have shown that strong insolation accounts for increased precipitation in the Indian monsoon region (Prell and Kutzbach, 1992; Clemens et al., 1996). These studies show that the Asian monsoon is sensitive to both the obliquity forcing and the precessional forcing but with non-stationary phase relation-
4, 719-740, 2008

Influence of orbital parameter on the

Asian monsoon

M. E. Hori et al.

\section{Title Page}

Abstract

Introduction

Conclusions

References

Tables

Figures



- I

$\checkmark$

\section{Close}

\section{Full Screen / Esc}

Printer-friendly Version

Interactive Discussion

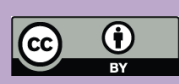


ships. Clemens et al. (1991) found strong coherence of Arabian Sea sediment record with the precessional forcing and related them to the strength of cross-equatorial transport and release of latent heat over the monsoon region. Through a simple sensitivity experiment, Clement and Seager et al. (1999) also showed that the tropical ocean5 atmosphere coupled system is sensitive to the precessional forcing due to interactions with the altered seasonality to the El-Niño Southern Oscillation (ENSO).

Previous studies were mostly concerned with the summer Asian monsoon; however, the Asian monsoon itself has various sub regions with differing seasonality and characteristic precipitation patterns. The earliest onset of precipitation in the Asian monsoon 10 is located over the Indochina peninsula during late April to early May, which is followed by the onset over the Bay of Bengal, Indian subcontinent and southern China (Wang and Lin Ho, 2002).

Seasonality of the insolation has a strong impact on such monsoon seasonal evolution. Lestari and Iwasaki (2006) conducted two sensitivity experiments where SST 15 seasonality is fixed at 1 April against the insolation seasonality and vise-versa. Their result shows that land-sea heating contrast created primarily by the insolation forcing creates a heat-low surrounding the Eurasian continent and thereby forming the basic monsoon westerly flow. The SST seasonality with a fixed solar insolation acts to reduce the land-sea thermal contrast, but enhances the monsoon westerly via the 20 strengthening of the Hadley circulation and effective angular momentum transport.

Changes in orbital parameter introduce not only an increase/decrease in the amount of solar radiation received during the monsoon season, but also the timing of the insolation forcing. In this study, the influence of orbital parameter on the seasonality and rationality of the Asian summer monsoon precipitation is examined using a coupled 5 atmosphere-ocean general circulation model (AOGCM).

We selected two time periods from the late Eemian, the $115 \mathrm{kya}$ B. P. and $125 \mathrm{~B}$. P. for our sensitivity experiments. The two are notable periods in the earth's past climate where the northern hemisphere insolation during summer was at its minimum (115 kya) and maximum (125 kya). The two periods have large difference in obliquity and nearly
$4,719-740,2008$

\section{Influence of orbital} parameter on the Asian monsoon

M. E. Hori et al.
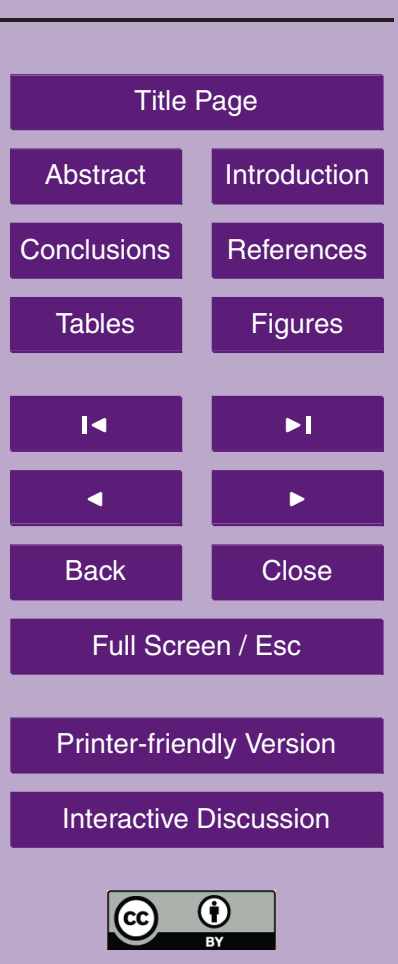


\section{Model experiment}

\subsection{Model explanation}

The AOGCM used is the MRI-CGCM2.3.2b developed by the Meteorological Research 5 Institute (Yukimoto et al., 2001). The resolution of the model is T42 in wave truncation which is approximately $2.8^{\circ} \times 2.8^{\circ}$ in longitude and latitude. There are 30 vertical levels in the model with a top at $0.4 \mathrm{hPa}$. The parameterization for deep moist convection is the Arakawa- Schubert scheme with prognostic closure.

The ocean model is a Bryan-Cox type general circulation model with a resolution of $102.5^{\circ}$ in longitude and $2^{\circ}$ in latitude poleward of $12^{\circ}$ in both hemispheres. In the tropics, the meridional resolution of the grid is higher in order to provide good resolution of equatorial oceanic waves. Heating of the ocean surface due to absorbed solar radiation is a constant of $e$ folding at $10 \mathrm{~m}$ depth. The seasonality of the model is retained through a flux adjustment of heat and freshwater which is obtained from the spin-up 15 run.

\subsection{Experimental design}

In order to quantify the effect of orbital forcing on the seasonality of the monsoon precipitation, we performed two simplified sensitivity experiments, one with an orbital forcing of the 115 kya period BP and another with the 125 kya period BP (referred to as the 115 kya and 125 kya experiment in the following text).

The imposed orbital parameters are calculated from Berger (1991) and are summarized in Table 1 . During the 125 kya period, the obliquity angle was greater and the longitude of perihelion was almost the opposite compared to the 115 kya period. Within the model experiments, the vernal equinox is fixed at 20 March, which causes

Influence of orbital parameter on the Asian monsoon

M. E. Hori et al.
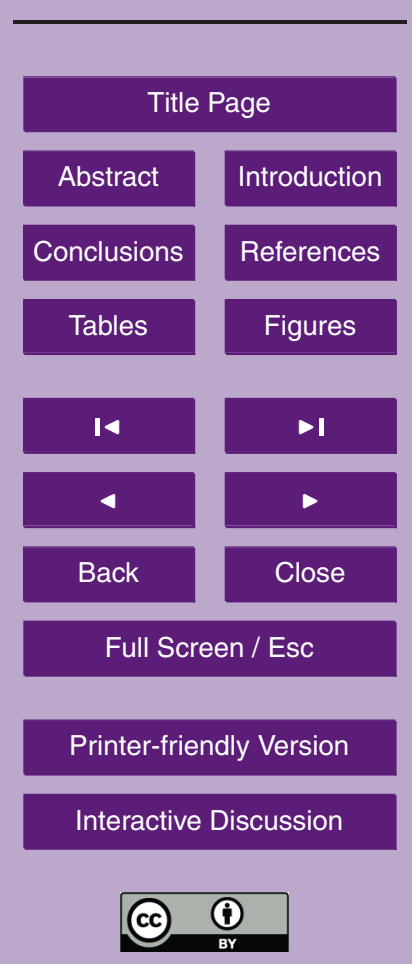
the perihelion to conincide with the boreal hemisphere summer for the $125 \mathrm{kya}$ experiment and coincide with the boreal winter for the $115 \mathrm{kya}$ experiment. This results in a large difference of seasonal cycle of insolation.

The amount of Greenhouse gas (GHG) concentration is constrained at the pre5 industrial level of $280 \mathrm{ppm}$ for $\mathrm{CO}_{2}, 700 \mathrm{ppb}$ for $\mathrm{CH}_{4}$, and $265 \mathrm{ppb}$ for $\mathrm{N}_{2} \mathrm{O}$ following the experiment setting of Cubasch et al. (2006). We did not use the historical reconstruction of GHG concentration for the particular time periods to constrain the model response to orbital forcing only. With the same rational, the sea level, continental icesheet, and vegetation distribution are all kept as the same as the present day control 0 experiment.

The sensitivity experiment is branched off from a long-term spin-up run, which is then integrated for 60 years. The first 10 years of integration is excluded from the model run to let the surface mixed layer of the ocean to adjust to the new boundary conditions. The climatology of the last 50 years of integration is used for the rest of this

study. Ideally, the ocean circulation should be stabilized through long-term integration. However, for the purpose of this study, the change in boundary condition is weaker compared to other changes (such as inclusion of continental ice-sheets, or a change in coast lines), and a 10 year spin-up time is sufficient for the ocean mixed layer to relax towards the imposed orbital parameters. The model also exerts an interannual to decadal variability in the tropical ocean due to simulated El-Niño fluctuations, which is effectively removed by taking a 50 year averaged climatology.

In addition, a long-term integration of the present-day control experiment is used as a reference to the two sensitivity experiments.

\section{Results}

25 Figure 1a shows the time series of July insolation at $15^{\circ} \mathrm{N}$ based on the calculation of Berger and Loutre (1991). Large difference of insolation can be seen in the Eemian interglacial period starting around 131 kya BP. The incoming radiation reaches a max-
$4,719-740,2008$

Influence of orbital parameter on the Asian monsoon

M. E. Hori et al.

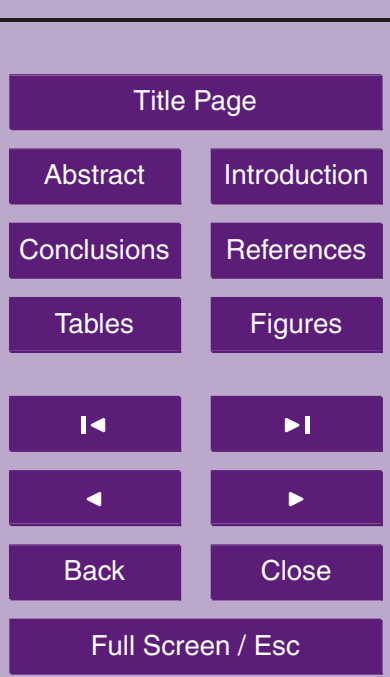

Printer-friendly Version

Interactive Discussion

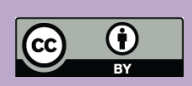


imum of $496 \mathrm{~W} / \mathrm{m}^{2}$ around $125 \mathrm{kya}$ and shows a minimum value of $417 \mathrm{~W} / \mathrm{m}^{2}$ around $115 \mathrm{kya}$. The $115 \mathrm{kya}$ period coincides with the last glacial inception and the $125 \mathrm{kya}$ period is known to correspond well with the warmest period in the Eemian glacial minimum.

5 Figure $1 \mathrm{~b}$ and $\mathrm{c}$ shows the simulated zonal averaged short-wave radiation at the top of the atmosphere for the 115 kya and 125 kya experiment, respectively. The contour denotes the incoming solar radiation and the shading corresponds to the anomaly against the present-day control experiment. It can be seen that during the $115 \mathrm{kya}$ period, negative anomaly in incoming radiation is largest in the boreal summer over northern hemisphere and in the boreal autumn for the southern hemisphere.

The absolute value of cooling (heating) anomaly in the $115 \mathrm{kya}$ (125 kya) during boreal summer is mostly a result of smaller (larger) obliquity angle of the earth's rotation axis. On the other hand, the slant of the anomaly extending from the boreal summer to autumn corresponds to a shift in seasonality of the incoming radiation and is a result of the precession of the earth's rotating axis. Due to these orbital effects, the meridional gradient in incoming solar radiation becomes diminished (enhanced) in the $115 \mathrm{kya}$ (125 kya) period.

There is also a notable change in seasonality of incoming radiation in the tropical area. During the 115 kya period, the tropics experiences an early anomalous heating 20 in excess of $30 \mathrm{~W} / \mathrm{m}^{2}$, which rapidly diminishes towards summer and autumn. The situation is reversed in the 125 kya period where the tropical region experiences a decreased solar radiation of over $50 \mathrm{~W} / \mathrm{m}^{2}$ in the boreal winter and during the following spring, which rapidly changes to a positive anomaly in the summer. Such change in seasonality exists mostly in the tropical area, with the mid-latitudes sharing only a part of this this anomaly.

This feature becomes much clear in Fig. 2, where a cross-section of Fig. $1 \mathrm{~b}$ and $\mathrm{c}$ is taken in a slab averaged over $20^{\circ}$ in latitude centered along $20^{\circ} \mathrm{N}$, the equator, and $20^{\circ} \mathrm{S}$ for each sensitivity experiments. In the northern hemisphere mid-latitudes, the incoming solar radiation is the largest during the summer for the 125 kya period. The

Influence of orbital parameter on the Asian monsoon

M. E. Hori et al. Title Page

Abstract Conclusions

Tables References Figures



Printer-friendly Version

Interactive Discussion

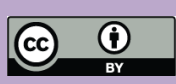


same seasonality is shared for the 115 kya period but with a diminished peak value. The shape of the seasonality is symmetric for the southern hemisphere where the solar radiation becoming a minimum in the boreal summer.

This seasonality changes drastically in the tropics. During the 115 kya period, the 5 maximum in solar radiation occurs in the early spring and takes a minimum value in the boreal summer. Seasonality for the 125 kya period is in strong contrast to the 115 kya period where the incoming radiation shows a minimum during the boreal winter and gradually increases towards early autumn where it becomes a maximum. This outof-phase relationship in the insolation over the tropical region is mostly a result of the precession of the earth's rotating axis, which has a large signal in the tropics.

Next, we examine the annual mean precipitation of the two experiments to access the effect of this altered seasonal evolution in insolation, which is shown in Fig. 3. The use of annual mean precipitation is meaningful in this case since any anomaly due to changes in orbital parameters tends to cancel out when it is averaged over the whole year, and an anomaly in annual precipitation is a result of the net effect of altered seasonality of the imposed insolation. Over the Indian subcontinent, there is a strong negative anomaly in the 115 kya period and a strong positive anomaly in the 125 kya period. This corresponds to a diminished (enhanced) monsoon precipitation for the $115 \mathrm{kya}$ ( $125 \mathrm{kya}$ ) period and is consistent with the findings of Prell and Kutzbach 20 (1992).

On the other hand, a salient positive anomaly (note that the range in Fig. $3 \mathrm{a}$ is half that of Fig. $3 \mathrm{~b}$ ) over the maritime continent region of equ. $-20^{\circ} \mathrm{N}, 90-140^{\circ} \mathrm{E}$ is observed for the 115 kya period. In the 125 kya period experiment, a strong negative precipitation anomaly replaces this feature and the signal is reversed.

This alternation of anomaly in precipitation between the Indian monsoon and the maritime continent region implies that in the absence of a strong Indian monsoon, the "maritime monsoon" over the tropical Southeast Asian monsoon becomes more dominant and vise-versa.

To examine the seasonality of these two contrasting regions the timeseries of area
4, 719-740, 2008

Influence of orbital parameter on the Asian monsoon

M. E. Hori et al. Title Page

Abstract

Introduction

Conclusions

References

Tables

Figures



Full Screen / Esc

Printer-friendly Version

Interactive Discussion

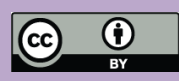


averaged precipitation for the Indian subcontinent region of $10-35^{\circ} \mathrm{N}, 70-90^{\circ} \mathrm{E}$ and the western Pacific region of equ. $-20^{\circ} \mathrm{N}, 90-140^{\circ} \mathrm{E}$ is summarized in Fig. 4 . In the Indian monsoon region, the seasonal precipitation reaches a maximum during the boreal summer season. The precipitation is larger for the $125 \mathrm{kya}$ experiment, which signifies 5 the effect of increased continental heating due to increase of insolation. On the other hand, the western Pacific region shows a shift in the monsoon season with an earlier onset of the monsoon in the 115 kya experiment. Also, precipitation is slightly higher for most months, which is indicative of an enhanced moisture convergence in the region throughout the year.

10 These two contrasting seasonality in precipitation can be explained by the fact that the Indian subcontinent lies in the mid-latitudes where obliquity forcing is more dominating, whereas the western Pacific maritime continent is influenced more strongly by the change in the seasonality of insolation due to the precessional signal.

Changes in the structure of the Asians summer monsoon between the two sensitivity 15 experiments are highlighted in the $850 \mathrm{hPa}$ wind vector and scalar wind speed shown in Fig. 5. In both figures, strong cross-equatorial wind flow and the monsoon westerly's can be seen. However, while the region of maximum monsoon westerly can be seen in the Bay of Bengal around $5^{\circ} \mathrm{N}, 80^{\circ} \mathrm{E}$ for the $115 \mathrm{kya}$ experiment, the $125 \mathrm{kya}$ experiment shows the maximum monsoon westerly near the Arabian sea around $10^{\circ} \mathrm{N}$, $2050^{\circ} \mathrm{E}$. In the $125 \mathrm{kya}$ experiment, the Somali jet is stronger than the $115 \mathrm{kya}$ experiment and a northern shift of the monsoon westerly near the Arabian Sea is notable.

Figure 6 shows the difference in vertically integrated moisture flux convergence with the 125 kya experiment subtracted from the 115 kya experiment. March to August average is taken to account for the earlier monsoon onset of the 115 kya experiment as well as the summer monsoon season depicted in the $125 \mathrm{kya}$ experiment. A positive (negative) value corresponds to a convergence of moisture in the lower troposphere in the $115 \mathrm{kya}(125 \mathrm{kya})$ experiment. It can be seen that east to the maximum wind monsoon westerly region in Fig. 5, there is a strong convergence, which in turn corresponds to the anomaly of precipitation in Fig. 3 . In the 115 kya experiment the monsoon westerly
4, 719-740, 2008

Influence of orbital parameter on the Asian monsoon

M. E. Hori et al.
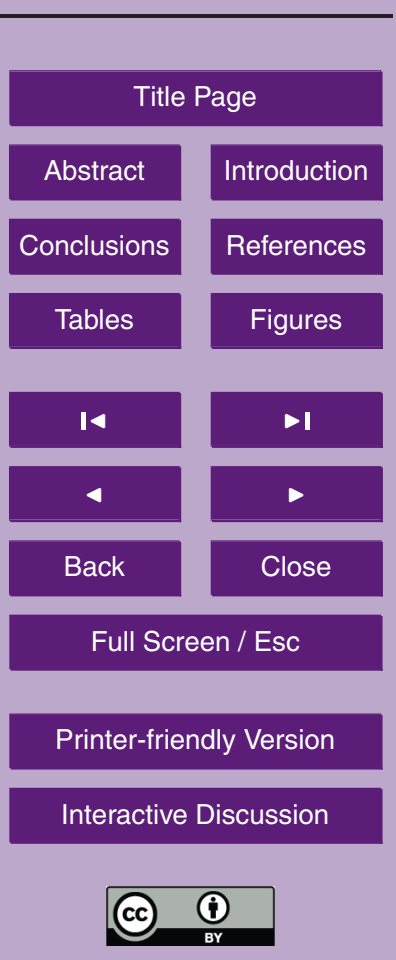
does not converge over the Indian subcontinent but over the Bay of Bengal and the maritime continent, whereas in the 125 kya experiment the monsoon westerly is much closer to the Arabian Peninsula and the convergence zone is located over the Indian subcontinent.

5 The reason for the strong cross-equatorial flow and monsoon westerly over the Arabian sea in the 125 kya experiment can be explained by the strong land surface heating due to obliquity forcing. Figure 7 shows the difference in surface temperature between the 125 kya experiment and the $115 \mathrm{kya}$ (in this case, the difference is calculated as the 125 kya experiment minus the 115 kya experiment for clarity) for the June to Au10 gust season. Strong heating of the land surface in excess of $4^{\circ} \mathrm{C}$ is discernable over northern Africa, the Arabian Peninsula, and much of the mid-latitudes. This positive difference in temperature is apparent in most of the lower troposphere (figure not shown) and corresponds to a stronger land-sea temperature gradient for the 125 kya experiment. Such temperature gradient is especially stronger over the coast of the Arabian 15 Peninsula, where the location of land surface heating is nearer to the ocean, which accounts for the maximum wind monsoon westerly in the Arabian Sea for the 125 kya experiment.

On the other hand, this signature becomes reversed in the 115 kya experiment that signifies a significant weakening of the heat-low over the continent and the monsoon westerly is displaced farther from the coastline.

In the absence of a strong continental heating due to obliquity forcing, the role of sea surface temperature (SST) becomes more evident in controlling the monsoon wind field. In Fig. 8, the SST seasonality and $850 \mathrm{hPa}$ wind field for the latitudinal section of equ. $-20^{\circ} \mathrm{N}$ is shown. In the $115 \mathrm{kya}$ experiment, the SST over the Arabian Sea and the Bay of Bengal becomes higher during the boreal spring. Early onset of the monsoon westerly is discernable as early as April and a strong convergence between the tropical trade wind can be seen in the $100-120^{\circ} \mathrm{E}$ region. In contrast, the $125 \mathrm{kya}$ experiment shows a maturing of SST in the boreal summer and autumn. This large difference in SST seasonality is closely tied to the difference in tropical seasonality of

4, 719-740, 2008

Influence of orbital parameter on the Asian monsoon

M. E. Hori et al.
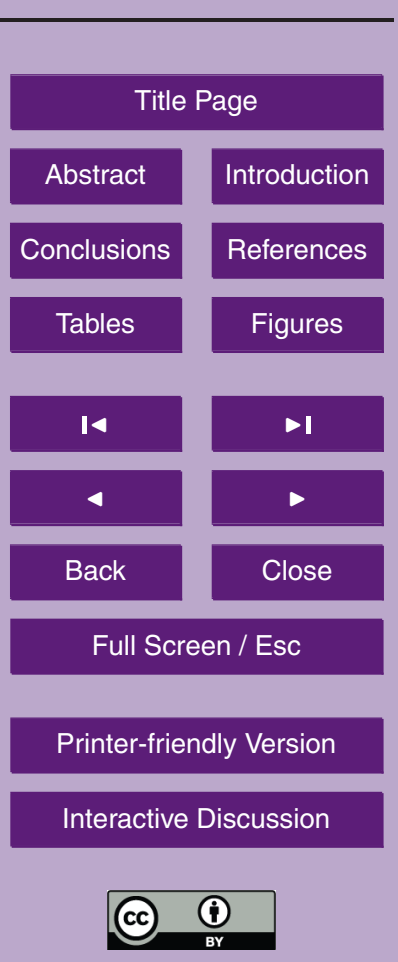
insolation shown in Fig. 2. The early warming of the SST in the 115 kya experiment coincides with the maximum insolation during boreal spring.

Figure 9 shows the difference of precipitation between the 115 kya experiment and $125 \mathrm{kya}$ experiment for the $0-20^{\circ} \mathrm{N}$ latitudinal section. The climatological precipitation 5 for the present day control run is shown in black contours as a reference. A positive anomaly is located in the spring season around $100-140^{\circ} \mathrm{E}$, which corresponds to the maturity of the SST beyond the $28.5^{\circ} \mathrm{C}$ threshold in the 115 kya experiment (Fig. 8a). A strong negative anomaly in the summer season near $80^{\circ} \mathrm{E}$ and the positive anomaly around $130^{\circ} \mathrm{E}$ correspond to a stronger Indian monsoon precipitation and an absence 10 of precipitation over the western Pacific region for the 125 kya experiment.

\section{Discussions and conclusion}

In this study, the influence of orbital forcing on the seasonality of the Asian monsoon precipitation has been examined using two sensitivity experiments using the MRICGCM climate model. Simplified sensitivity experiments for the contrasting orbital 15 parameters in the late Eemian period of $115 \mathrm{kya}$ B. P. and $125 \mathrm{kya}$ B. P. showed an enhancement of the western Pacific maritime continent monsoon and a weakening of the Indian monsoon for the 115 kya experiment and a reversed signal for the $125 \mathrm{kya}$ experiment.

Changes in the Indian monsoon is sensitive to the obliquity parameter which cre20 ates a heating over the continent which drives a stronger cross-equatorial flow and a maximum of monsoon westerly in the coast of the Arabian peninsula. In the absence of such obliquity forcing in the mid-latitudes, the monsoon westerly converges in the western Pacific region thereby enhancing the maritime monsoon precipitation. The enhancement of this maritime monsoon has a different seasonality than the obliquity

Such maritime monsoon precipitation has a weaker sensitivity than the Indian monsoon where the level of variability is roughly half of that of the Indian monsoon (see

$4,719-740,2008$

Influence of orbital parameter on the Asian monsoon

M. E. Hori et al.

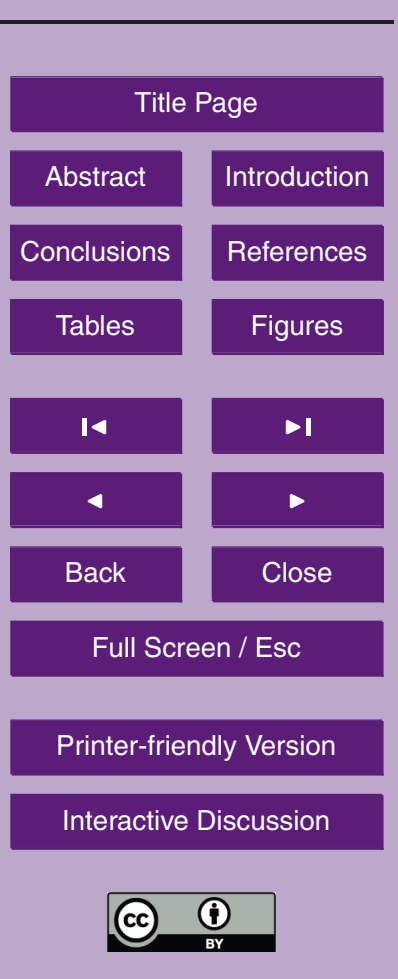


Fig. 3). Thus the response of regional precipitation to changes in both the obliquity and the precessional signal will become strongly non-linear.

In any case, the result of this study shows that there is strong possibility that the monsoon seasonality will be shifted and the total amount of rainfall may be influenced due to 5 the precessional parameter especially in the western Pacific and Indochina peninsula. Most paleoclimate records do not retain any seasonality and only gives a representative reference value for a given period of time. Results of this study shows that for a more detailed interpretation of such paleoclimate records, it may be suitable to take such changes in seasonality into account rather than assuming that all precipitation 10 occurs during the boreal summer.

Since this is a simplified sensitivity experiment with no changes in GHG concentrations or changes in ice-sheet and vegetation distributions, further studies are required to fully understand the contrasting effect of the obliquity and precessional parameters on the monsoon seasonality. Also, the monsoon variability and seasonality is strongly 15 affected by the strength of the ENSO variability in the eastern tropics. The seasonality of SST in the central to eastern Pacific is strongly influenced by the precessional parameters (Fig. 8) which may have a strong impact on the simulated ENSO seasonality and its coupling with the Asian monsoon. These issues are to be addressed in the future using an LGM boundary condition to execute similar sensitivity experiments.

20 Acknowledgements. The authors thank Shukuro Manabe of Princeton University for his encouragement and discussions during the course of this study. O. Arakawa and S. Murakami of the Meteorological Research Institute provided technical assistance for the GCM experiments.

\section{References}

Berger A. and Loutre, M. F.: Insolation values for the climate of the last 10 million of years, Quaternary Sci. Rev., 104, 297-317, 1991.

Clemens, S. C., Murray, D. W., and Prell, W. L.: Nonstationary phase of the plio-pleistocene Asian monsoon, Science, 274(5289), 943-948, 1996.

4, 719-740, 2008

Influence of orbital parameter on the Asian monsoon

M. E. Hori et al.
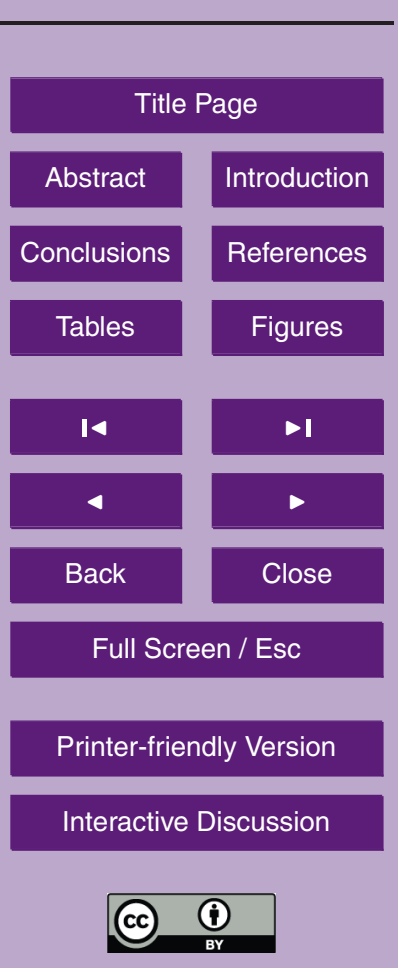
Clemens, S., Prell, W., Murray, D., Schimmield, G., and Weedon, G.: Forcing Mechanisms of the Indian-Ocean Monsoon, Nature, 353(6346), 720-725, 1991.

Clement, A. C., Seager, R., and Cane, M. A.: Orbital controls on the El Nino/Southern Oscillation and the tropical climate, Paleoceanography, 14(4), 441-456, 1999.

5 Cubasch, U., Zorita, E., Kaspar, F., et al.: Simulation of the role of solar and orbital forcing on climate, Particle Acceleration, Space Plasma Physics, Solar Radiation and the Earth's Atmosphere and Climate, 37(8), 1629-1634, 2006.

Lestari, R. K. and Iwasaki, T.: A GCM study on the roles of the seasonal marches of the SST and land-sea thermal contrast in the onset of the Asian summer monsoon, J. Meteorol. Soc. Jpn., 84(1), 69-83, 2006.

Prell, W. L. and Kutzbach, J. E.: Sensitivity of the Indian Monsoon to Forcing Parameters and Implications for Its Evolution, Nature, 360, 647-652, 1992.

Wang, B. and LinHo: Rainy season of the Asian-Pacific summer monsoon, J. Climate, 15(4), 386-398, 2002.
4, 719-740, 2008

Influence of orbital parameter on the Asian monsoon

M. E. Hori et al.

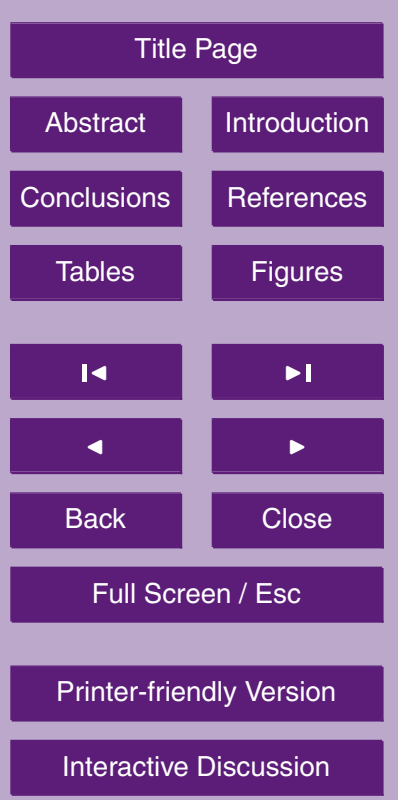


$4,719-740,2008$

\section{Influence of orbital} parameter on the Asian monsoon

M. E. Hori et al.

Table 1. Orbital parameters for the sensitivity experiments. Orbital parameters are taken from Berger (1991).

\begin{tabular}{cccc}
\hline & Obliquity & Longitude of perihelion & Eccentricity \\
\hline 115 kya BP & 22.438 & 109.54 & 0.043983 \\
125 kya BP & 23.818 & 304.76 & 0.042308
\end{tabular}

Title Page

Abstract

Introduction

Conclusions

References

Tables

Figures

14



Back

Full Screen / Esc

Printer-friendly Version

Interactive Discussion 


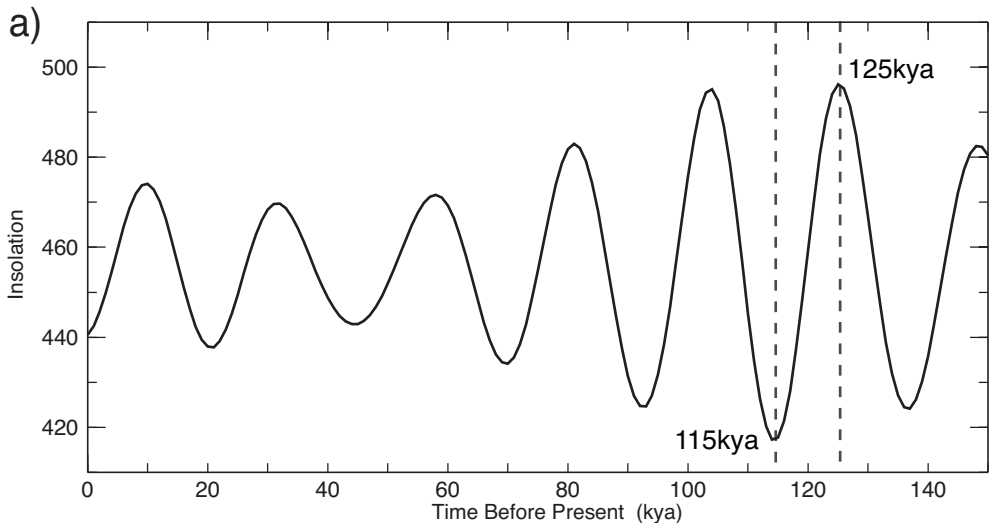

b)



Fig. 1. (a) Timeseries of July insolation at $15^{\circ} \mathrm{N}$. Units in $\mathrm{W} / \mathrm{m}^{2}$, (b) Zonal mean averaged seasonality of incoming short-wave radiation at the top of the atmosphere for the $115 \mathrm{kya}$ B. P. experiment. Contours denote the insolation and shadings denote the anomaly from the present day control experiment, (c) Same as (b) but for the 125 kya B. P. experiment.
4, 719-740, 2008

Influence of orbital parameter on the Asian monsoon

M. E. Hori et al.

\section{Title Page}

Abstract

Introduction

Conclusions

References

Tables

Figures
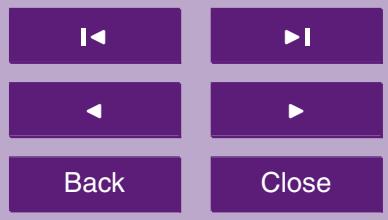

Back

Close

\section{Full Screen / Esc}

Printer-friendly Version

Interactive Discussion

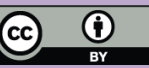




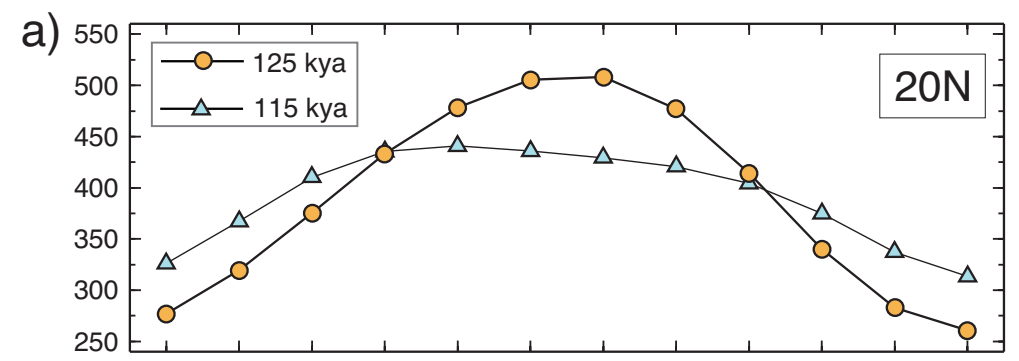

b)



c)

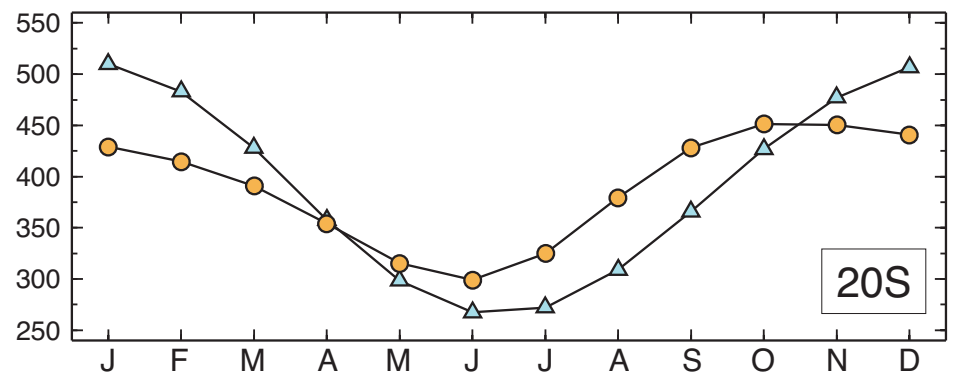

Fig. 2. Seasonality of insolation for the two sensitivity experiments averaged over the $20^{\circ}$ latitudinal section centered at (a) $20^{\circ} \mathrm{N}$, (b) the equator, (c) $20^{\circ} \mathrm{S}$. Units in $\mathrm{W} / \mathrm{m}^{2}$.
4, 719-740, 2008

\section{Influence of orbital} parameter on the Asian monsoon

M. E. Hori et al.

\section{Title Page}

\section{Abstract}

Introduction

Conclusions

References

Tables

Figures

\begin{tabular}{|c|c|}
\hline Close \\
\hline Back \\
\hline Full Screen / Esc \\
\hline
\end{tabular}

Printer-friendly Version

Interactive Discussion





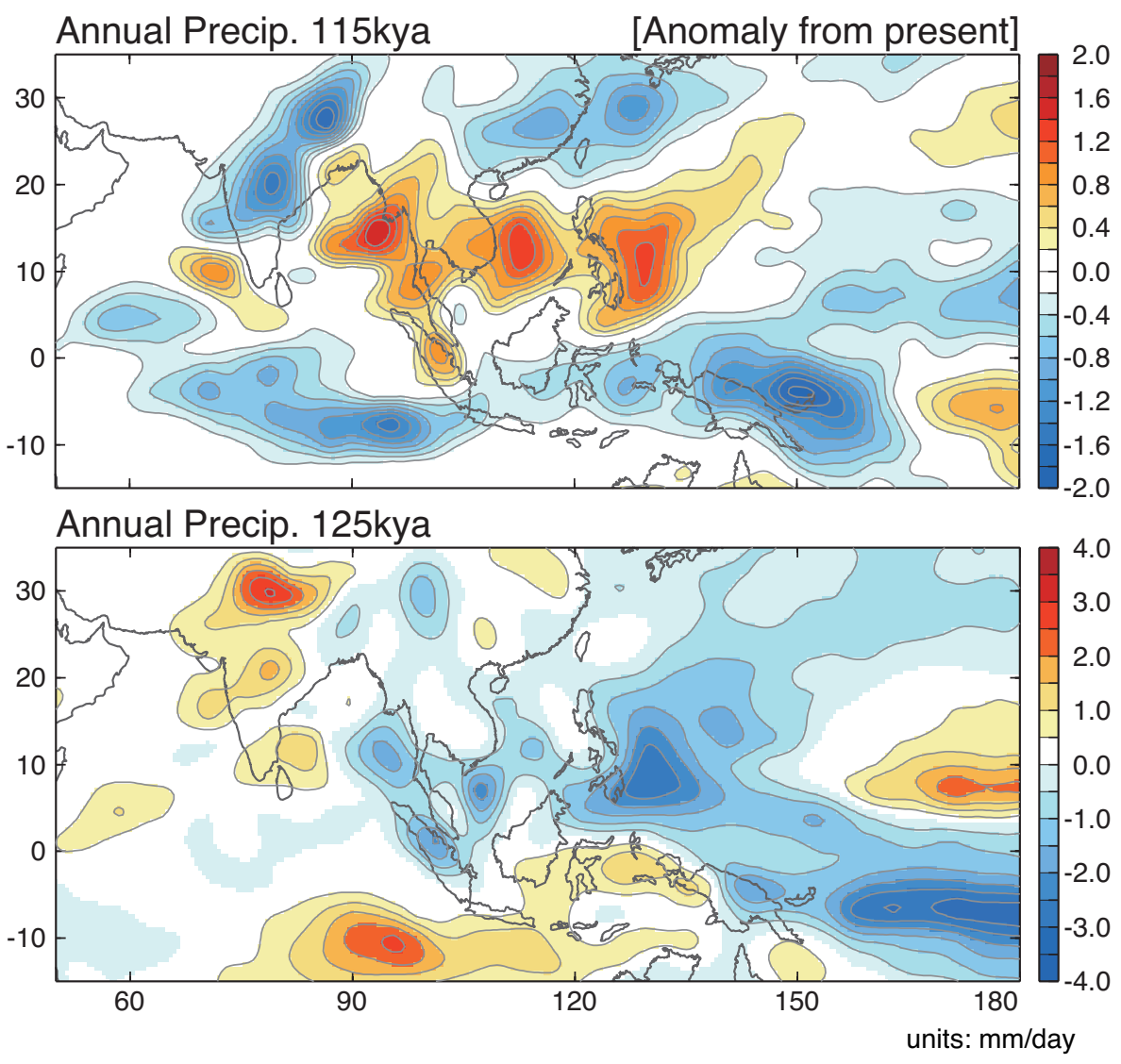

Title Page

Influence of orbital parameter on the Asian monsoon

M. E. Hori et al.

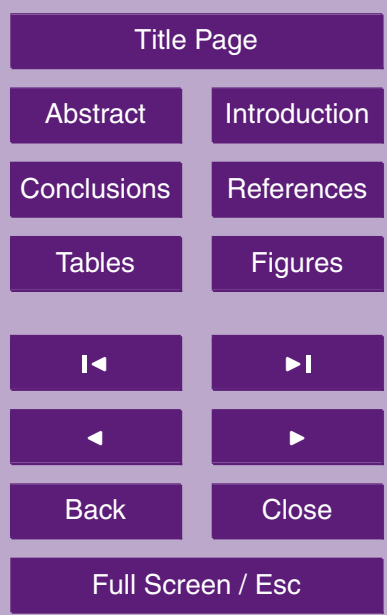

Fig. 3. Anomaly of annual precipitation from the present day control experiment for (a) the 115 kya B. P. experiment, and (b) the 125 kya B. P. experiment. Units in $\mathrm{mm} /$ day.

Printer-friendly Version

Interactive Discussion 



\section{Influence of orbital parameter on the Asian monsoon}

M. E. Hori et al.

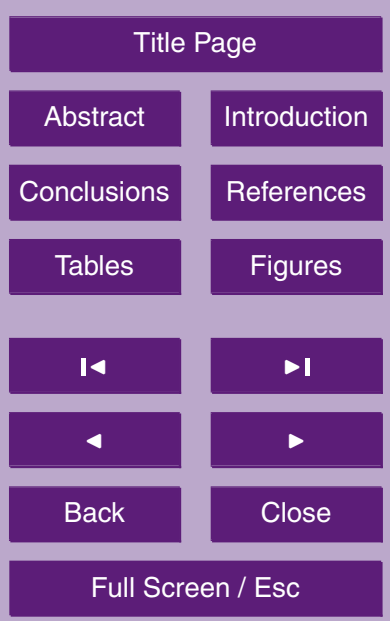

Fig. 4. Seasonality of the precipitation for the two sensitivity experiments over (a) the Indian subcontinent region of $10-35^{\circ} \mathrm{N}, 70-90^{\circ} \mathrm{E}$, and (b) the western Pacific region of $0-20^{\circ} \mathrm{N}, 90-$ $140^{\circ} \mathrm{E}$. Units in $\mathrm{mm} /$ day.

Printer-friendly Version

Interactive Discussion 


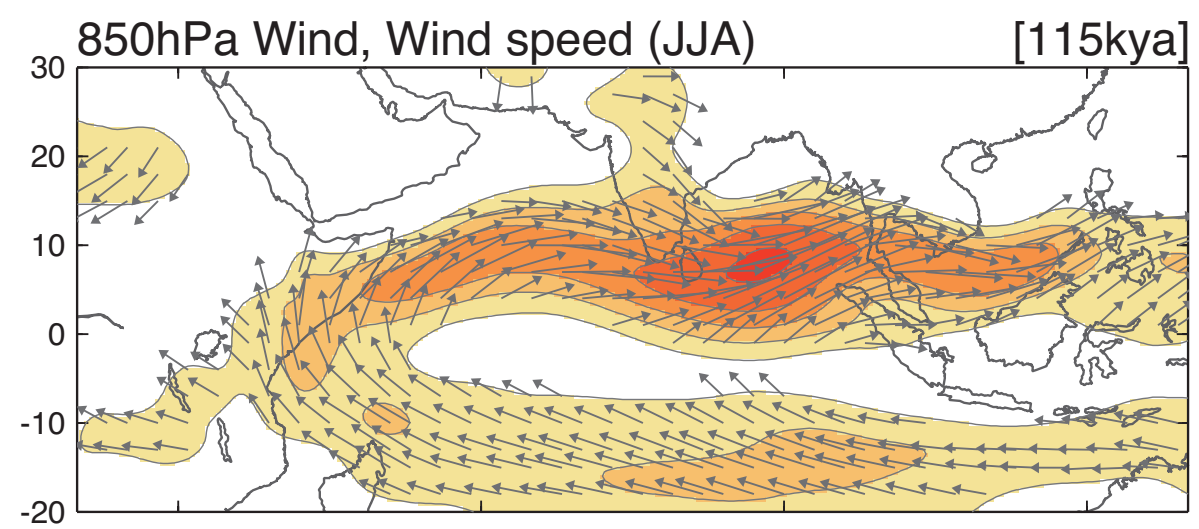

4, 719-740, 2008

Influence of orbital parameter on the Asian monsoon

M. E. Hori et al.

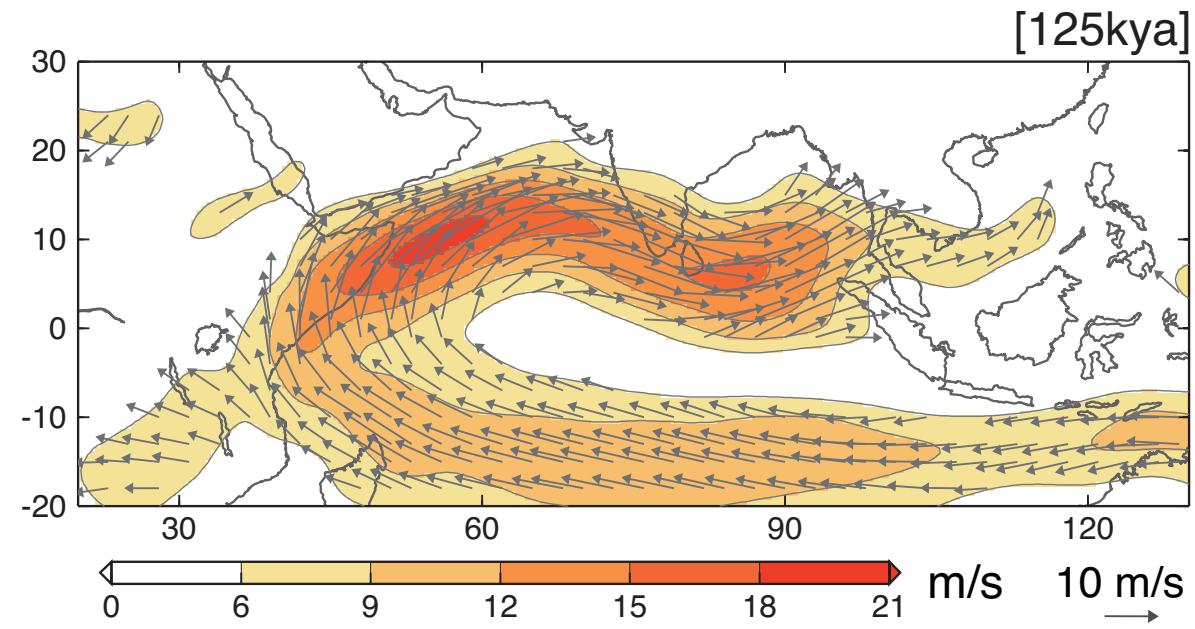

Title Page

\begin{tabular}{c|c}
\hline Abstract & Introduction \\
\hline Conclusions & References \\
\hline Tables & Figures \\
\hline I4 & $\bullet \mathbf{I}$ \\
\hline 4 & $\triangleright$ \\
\hline Back & Close \\
\hline Full Screen / Esc
\end{tabular}

Printer-friendly Version

Fig. 5. The June to August averaged $850 \mathrm{hPa}$ wind vector and scalar wind speed for (a) the 115 kya B. P. experiment and (b) the 125 kya B. P. experiment. Vectors with wind speed less than $6 \mathrm{~m} / \mathrm{s}$ is now drawn.

Interactive Discussion

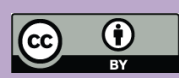




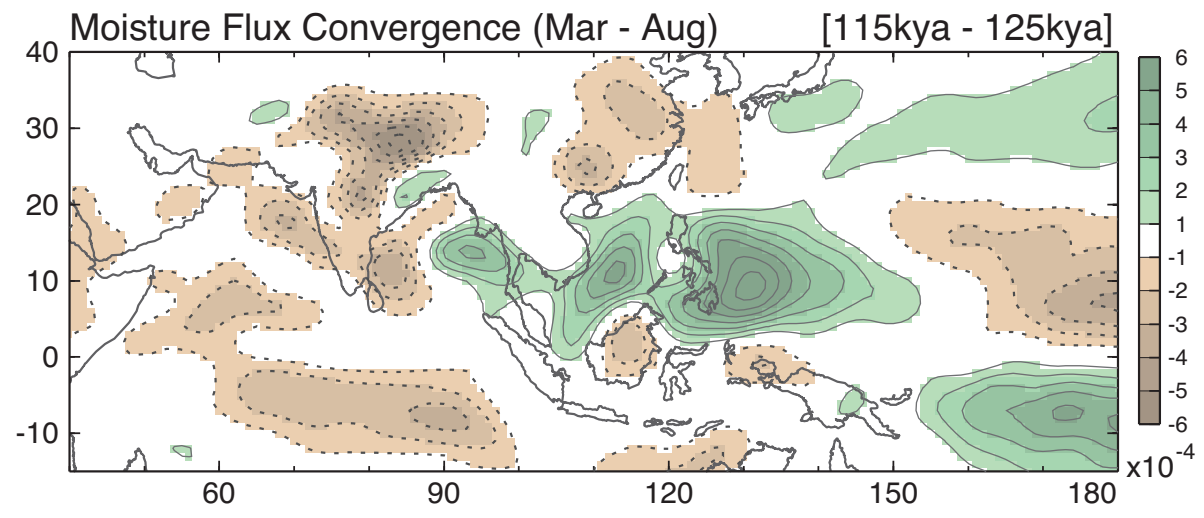

Fig. 6. Difference in convergence of the vertically integrated moisture flux averaged over March through August. Positive (negative) value corresponds to a convergence of moisture for the 115 kya (125 kya) experiment.

\section{Influence of orbital} parameter on the Asian monsoon

M. E. Hori et al.

\begin{tabular}{|c|c|}
\hline \multicolumn{2}{|c|}{ Title Page } \\
\hline Abstract & Introduction \\
\hline Conclusions & References \\
\hline Tables & Figures \\
\hline I & \\
\hline 4 & $\bullet \mathbf{I}$ \\
\hline Back & Close \\
\hline Full Screen / Esc
\end{tabular}

Printer-friendly Version

Interactive Discussion 


\section{Influence of orbital} parameter on the Asian monsoon

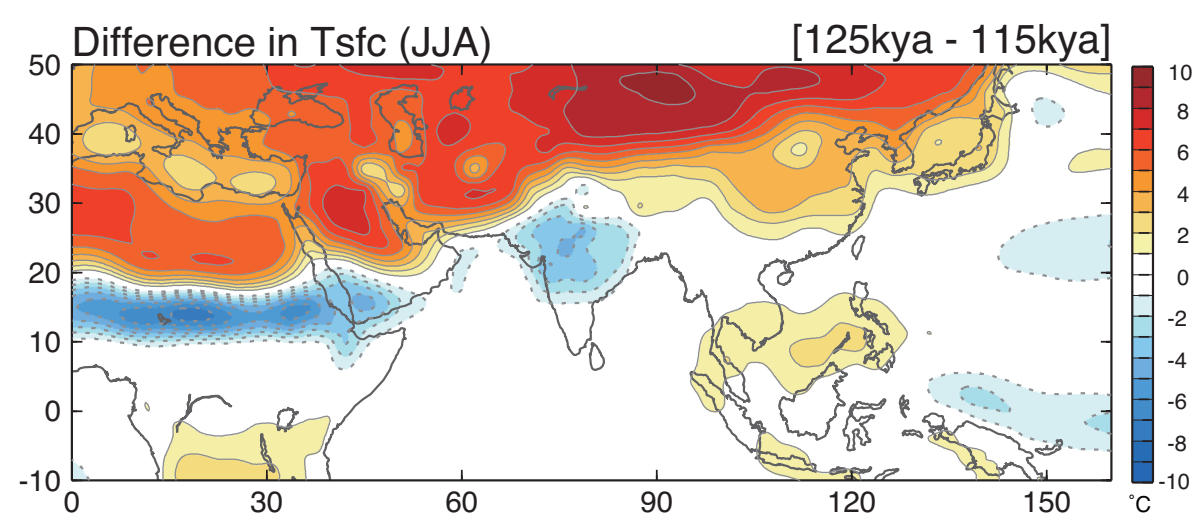

Fig. 7. Difference in surface temperature for the June to August season. The difference is for 125 kya B. P. experiment minus the 115 kya B. P. experiment. Units in ${ }^{\circ} \mathrm{C}$.
M. E. Hori et al.

\begin{tabular}{|c|c|}
\hline \multicolumn{2}{|c|}{ Title Page } \\
\hline Abstract & Introduction \\
\hline Conclusions & References \\
\hline Tables & Figures \\
\hline I4 & \\
\hline 4 & - I \\
\hline Back & Close \\
\hline Full Screen / Esc
\end{tabular}

Printer-friendly Version

Interactive Discussion 


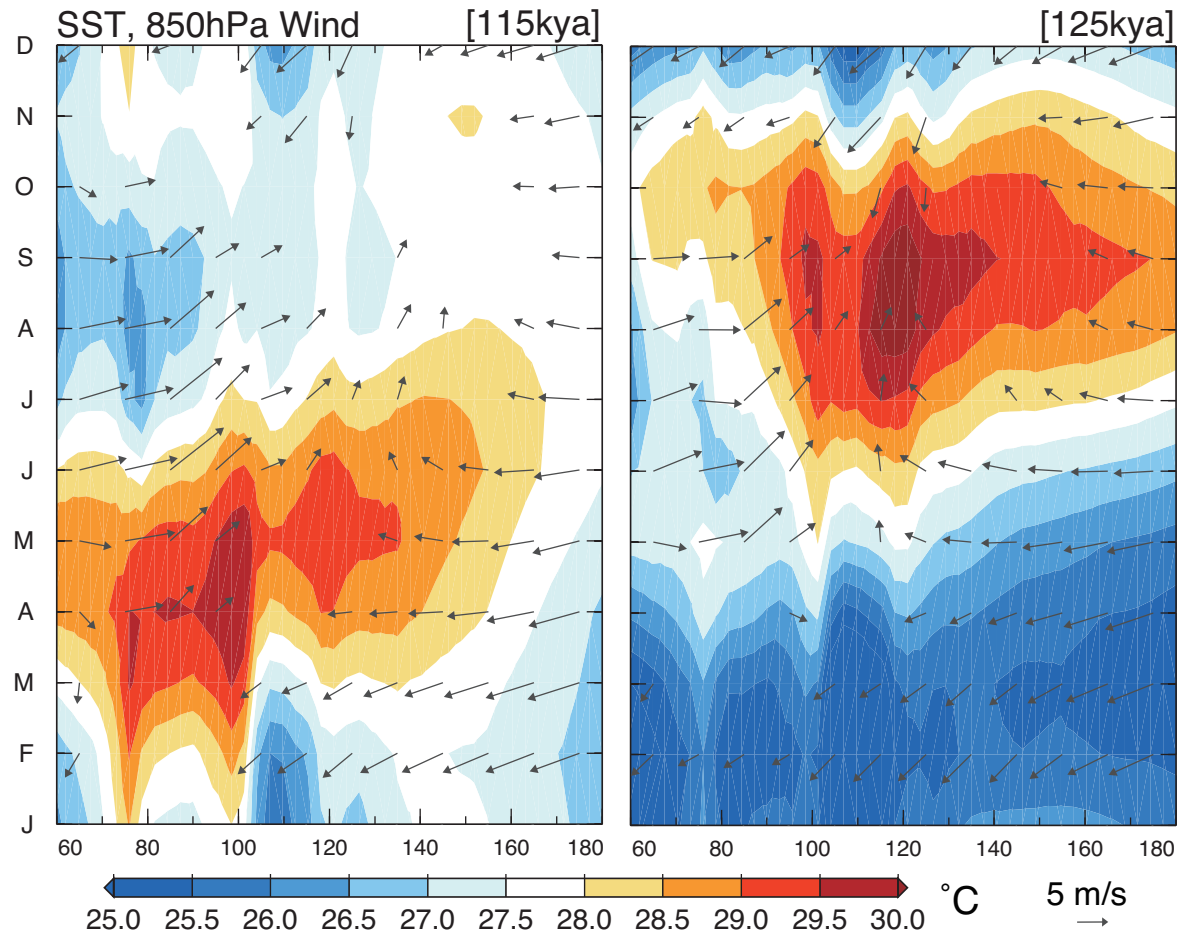

Fig. 8. Seasonality of sea surface temperature (SST) and $850 \mathrm{hPa}$ wind field averaged over the equator to $20^{\circ} \mathrm{N}$ latitudinal section. Wind vectors weaker than $6 \mathrm{~m} / \mathrm{s}$ in scalar wind speed is not drawn. Units of $\mathrm{SST}$ in ${ }^{\circ} \mathrm{C}$, and wind in $\mathrm{m} / \mathrm{s}$.
4, 719-740, 2008

Influence of orbital parameter on the Asian monsoon

M. E. Hori et al.

Title Page

\begin{tabular}{c|c|}
\hline Abstract & Introduction \\
\hline Conclusions & References \\
\hline Tables & Figures \\
\hline I & $\bullet$ \\
\hline 4 & $\triangleright$ \\
\hline Back & Close \\
\hline Full Screen / Esc
\end{tabular}

Printer-friendly Version

Interactive Discussion

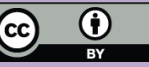




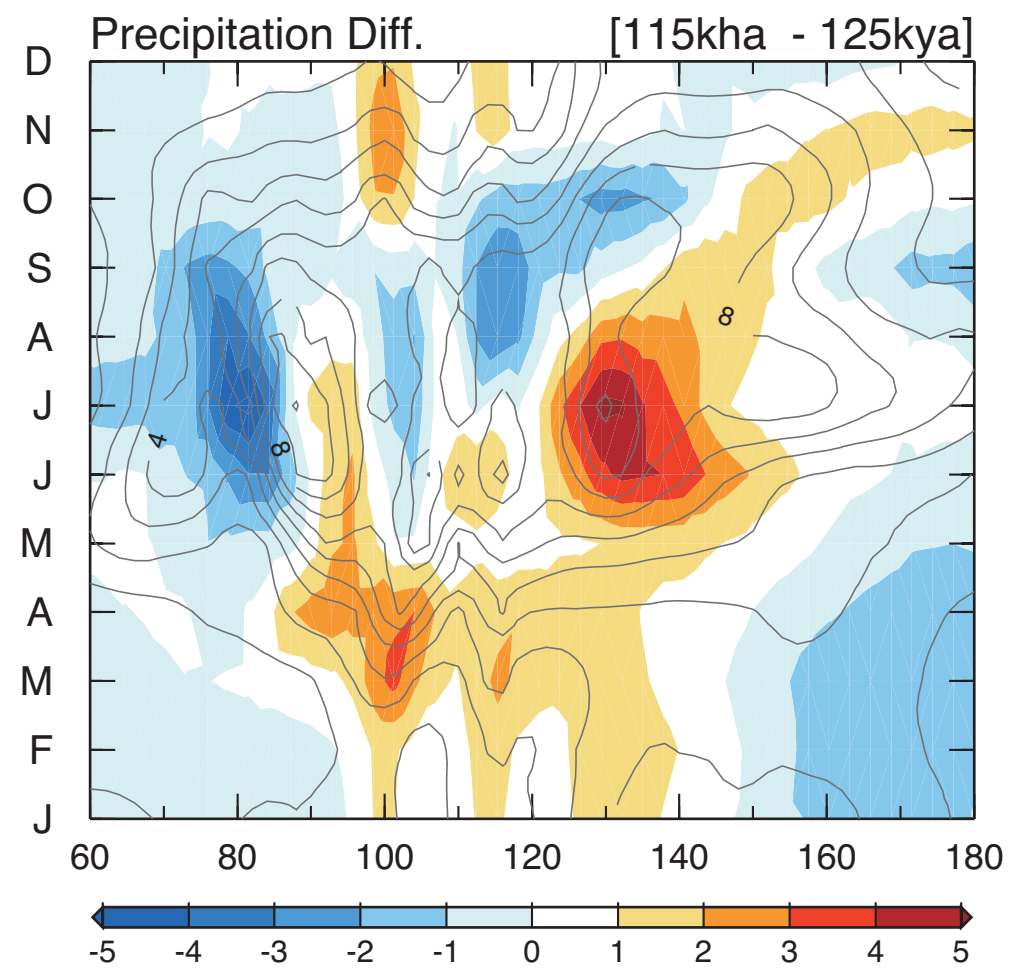

Fig. 9. Difference in precipitation between the $115 \mathrm{kya}$ B. P. experiment and the $125 \mathrm{kya}$ B. P. experiment averaged over the equator to $20^{\circ} \mathrm{C}$ latitudinal section. Shades denote the difference. Black contours denote the climatological precipitation for the present day control run. Units in $\mathrm{mm} /$ day.
$4,719-740,2008$

Influence of orbital parameter on the Asian monsoon

M. E. Hori et al. Title Page

\begin{tabular}{c|c|}
\hline Abstract & Introduction \\
\hline Conclusions & References \\
\hline Tables & Figures \\
\hline I4 & - I \\
\hline 4 & - \\
\hline Back & Close \\
\hline Full Screen / Esc
\end{tabular}

Printer-friendly Version

Interactive Discussion

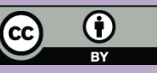

